\title{
The eye-bulging in Liolaemus lizards (Weigmann 1843)
}

\section{Protrusión ocular en lagartos Liolaemus (Weigmann 1843)}

\author{
Claudio Reyes-Olivares ${ }^{1, *}$, Inger Rain-Garrido² \& Antonieta Labra ${ }^{1,3}$ \\ ${ }^{1}$ Instituto de Ciencias Biomédicas, Facultad de Medicina, Universidad de Chile, 8380453 Santiago, Chile. \\ 2Superintendencia de Educación, Ministerio de Educación, Gobierno de Chile, 8340456 Santiago, Chile. \\ ${ }^{3}$ Centre for Ecological and Evolutionary Synthesis (CEES), Department of Biosciences, University of Oslo, NO-0316 Oslo, \\ Norway. \\ *E-mail: creyeso@ug.uchile.cl
}

\begin{abstract}
It is described for the first time the eye-bulging display in two liolaemid lizards, Liolaemus chiliensis and L. gravenhorstii. This display occurs in very low frequency and it was observed in captivity. It is discussed the possibility that the thermoregulation and/or eye-cleaning hypotheses may explain the occurrence of this display in these two species.
\end{abstract}

KEYwoRDs: Eye cleaning, Liolaemus chiliensis, Liolaemus gravenhorstii, thermoregulatory mechanism

\section{RESUMEN}

En este trabajo se describe por primera vez el despliegue de protrusión ocular en dos lagartos Liolaemidos, Liolaemus chiliensis y L. gravenhorstii. El despliegue ocurre en muy baja frecuencia y fue observado en cautiverio. Se discute la posibilidad de que las hipótesis de termorregulación y/o de limpieza de ojos puedan explicar la ocurrencia de este despliegue en estas dos especies.

Palabras claves: Limpieza de ojos, Liolaemus chiliensis, Liolaemus gravenhorstii, mecanismo termorregulatorio

The eye-bulging or eye-popping is a display in which eyes protrude simultaneously (Bruner 1907, Heath 1966, Steyn \& Steyn 1970), described in detail by Bruner (1907) and Heath (1966). Presently, it has only been observed in captive Iguania lizards from four families, Agamidae (Steyn \& Steyn 1970), Dactyloidae (Bruner 1907), Iguanidae (DeWitt 1967, Montanucci 1997) and Phrynosomatidae (Bruner 1907, Heath 1964, 1966, Phillips \& Harlow 1981). It has been considered a thermoregulatory mechanism that allows reducing the head temperature when this surpasses the body temperature (Heath 1964, Tattersall et al. 2006); when the warm blood of the head is shunted to the rest of the body during the thermoregulation, it produces a high blood pressure within the sinus orbitalis, which finally causes the eye protrusion (Bruner 1907, Heath 1966). However, the eye-bulging might also allow removing from the eyes sand or ectoparasites (Steyn \& Steyn 1970, Montanucci 1997), as well as shedding remnants (Bruner 1907).

Here, we describe for the first time the eye-bulging display in lizard species of the Neotropical genus Liolaemus
(Iguania: Liolaemidae): L. chiliensis (Lesson 1830) and L. gravenhorstii (Gray 1845), both from Melipilla, central Chile $\left(33^{\circ} 41^{\prime} \mathrm{S}, 71^{\circ} 13^{\prime} \mathrm{W}\right)$. As part of an ongoing study, we filmed in the laboratory the behavior of both species $(29 \mathrm{~L}$. chiliensis and three L. gravenhorstii), between December 2012 to February 2013. Lizards were placed individually in a plastic enclosure $(44.5 \times 32 \times 25 \mathrm{~cm})$, and this was positioned $60 \mathrm{~cm}$ below a video camera Panasonic HDCTM20 camcorder, to film the lizard behavior for 12 minutes by trial. Before each experiment, lizards were exposed to a source of heat (e.g. infrared or sun light) to allow them to actively thermoregulate. At the end of the trials, we recorded the lizard cloacal temperature $\left({ }^{\circ} \mathrm{C}\right.$; mean $\left.\pm \mathrm{SD}\right)$, to ensure that individuals were within the selected body temperature of Liolaemus lizards $\left(\sim 35^{\circ} \mathrm{C}\right.$; Labra et al. 2009), considering that the behavioural displays are affected by body temperature (Huey 1982).

We obtained 107 videos from L. chiliensis, as 20 individuals were filmed in four experimental conditions, while the rest, in three conditions. Only nine individuals of L. chiliensis 
(3 0,6 9) displayed eye-bulging, one of these lizards exhibited it twice in a trial, three other individuals displayed in two different trials, and the rest exhibited the display only once by trial. In the case of $L$. gravenhorstii, we obtained six videos, as each individual was recorded in two experimentals conditions. Only two males displayed eye protrusion, one did it only once in a trial while the other did it twice in a trial. In summary, from the 113 videos from both species in only 14 of these the lizards exhibited eye-bulging displays. For the characterization of the eye-bulging, when an individual exhibited more than once the display, we used the average of all its displays, to avoid pseudoreplication.

Usually lizards displayed only one eye-bulging during a trial (Fig. 1), except by two lizards that did it twice, one of each species. The description and duration of the eye-bulging are in Figure 2. Similar to what Bruner (1907) described, the display in these two species begin with a gradual and simultaneous distension of the eye balls completely covered by the eyelids (Stage I or stage of distension, sensu Bruner 1907). This is followed by the Stage II or stage of high pressure (sensu Bruner 1907), which consists in repeated events of maximum protrusion (Fig. 1 right panel) associated with dorsal neck contractions (Fig. 2), separated by periods of low ocular pressure that lasted about $2 \mathrm{~s}$. During this stage, the display looks like 'ocular pulses', and species exhibited an average of $3 \pm 1$ ocular pulses. Thereafter, eyes begin to retreat simultaneously, always covered completely by the eyelid, until they returned to their original position (Stage III or stage of retraction, Fig. 2), which in some few cases $(20 \%)$ was accompanied by tongue flicks to the air. No spasmodic movements of the neck were observed in this stage. Lizards were always immobile when they displayed eye-bulging, with the head up, closed mouth, except when they made tongue flicks in the last stage. Moreover, in the $40 \%$ of the eye-bulging displays, individuals decreased the breathing rate, determined by the flank movements, while in the other cases, the breathing was normal. Videos of the display can be requested to the authors. The lizard cloacal temperatures at the end of the experiments were $35.7 \pm 1.4$ ${ }^{\circ} \mathrm{C}$ and $35.1 \pm 0.8{ }^{\circ} \mathrm{C}$ for L. chiliensis and L. gravenhorstii, respectively, values that correspond to the selected body temperatures of the Liolaemus species from central Chile (Labra et al. 2009).
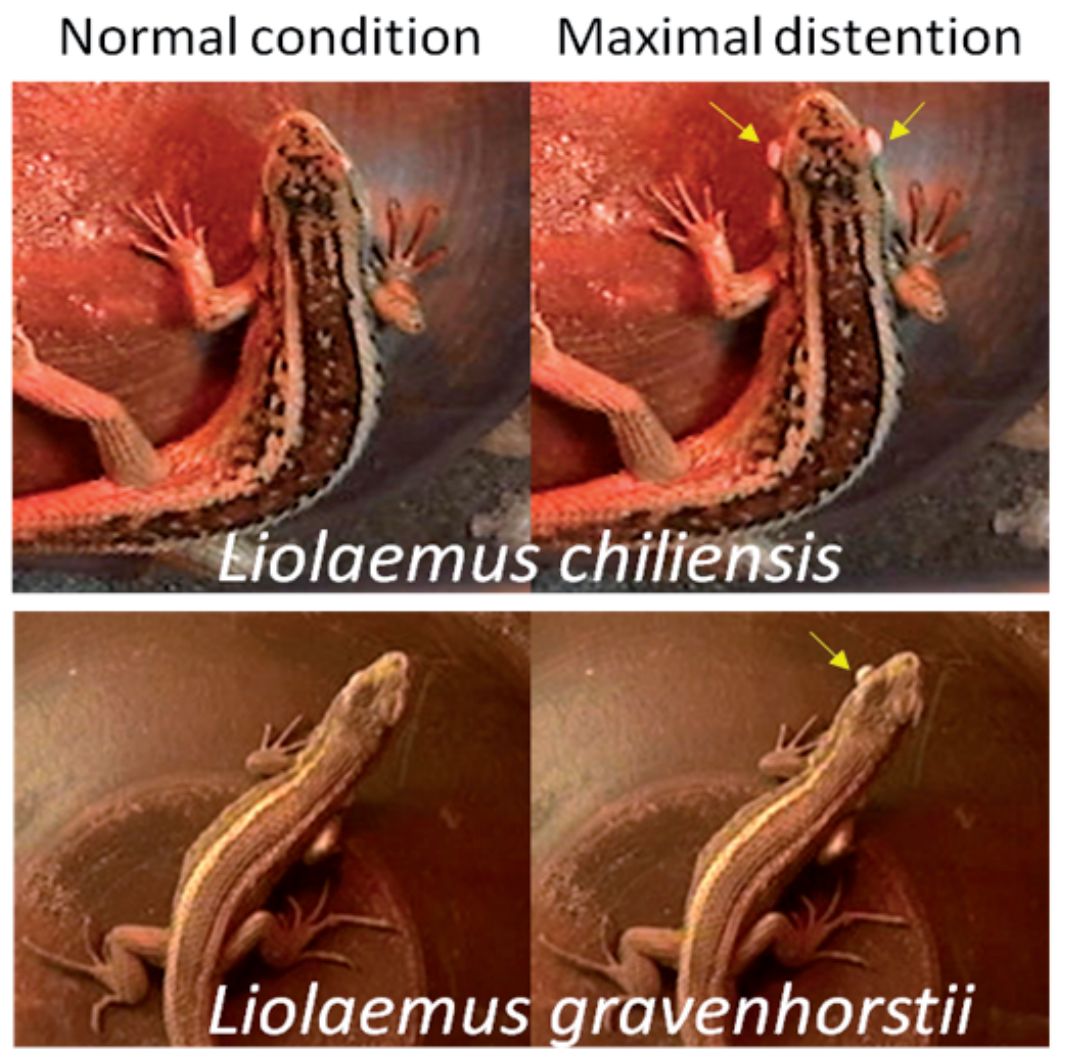

FIGURE 1. Eye-bulging of Liolaemus chiliensis and L. gravenhorstii. In the left panel, the normal condition, without eye-bulging, and in the right panel it is shown the maximal eye protrusion (Stage II), indicated by the yellow arrows. Note that eyes are covered by the eyelid.

FiguRa 1. Protrusión ocular de Liolaemus chiliensis y L. gravenhorstii. En el panel izquierdo se muestra la condición normal, sin protrusión ocular, y en el panel derecho se muestra la protrusión máxima del ojo (Etapa II), indicada con flechas amarillas. Note que los ojos están cubiertos por los párpados. 


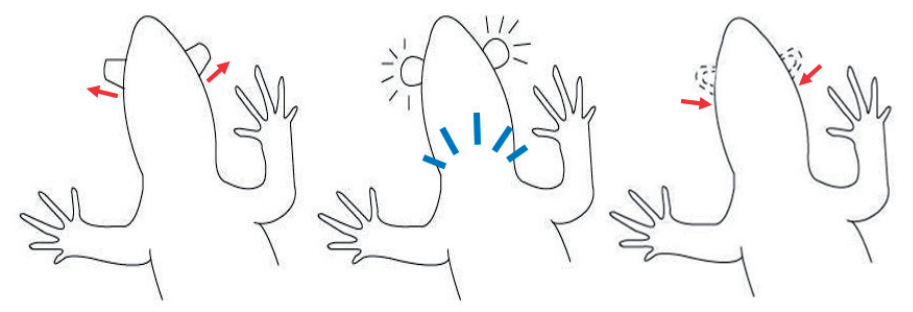

\begin{tabular}{llccc} 
& \multicolumn{4}{c}{ Duration (s) } \\
\cline { 2 - 5 } Species & Stage I & Stage II & Stage III & Total (Range) \\
L. chiliensis & $5.0 \pm 2.4$ & $3.8 \pm 1.9$ & $6.4 \pm 4.7$ & $15.2 \pm 5.0(10-26)$ \\
L. gravenhorstii & $4.0 \pm 0.0$ & $3.5 \pm 0.7$ & $6.8 \pm 3.9$ & $14.2 \pm 3.2(12-20)$
\end{tabular}

FIGURE 2. Duration ( $s$; mean $\pm \mathrm{SD}$ ) of each stages and the total of the eye-bulging, observed in Liolaemus chiliensis and L. gravenhorstii. In parentheses, it is given the maximal and minimal total duration. i) Stage I or stage of distension, ii) Stage II or stage of high pressure, and iii) Stage III or stage of retraction, when eyeballs return to their normal condition. The red arrows show the direction of the eye movement and the blue lines represent dorsal neck contraction. For more details of the description see the text.

Figura 2. Duración (s; promedio \pm DE) de cada etapa y del total de la protrusión ocular, observada en Liolaemus chiliensis y L. gravenhorstii. En paréntesis, se indica la duración total máxima y mínima. i) Etapa I o etapa de distensión, ii) Etapa II o etapa de alta presión, y iii) Etapa III o etapa de retracción, dada cuando los ojos vuelven a su condición normal. Las flechas rojas indican la dirección del movimiento ocular y la lineas azules representan la contracción dorsal del cuello. Para más detalles de la descripción ver el texto.

It has been suggested that the eye-bulging display is involved in the redistribution of the blood, allowing lizards to reach their optimal body temperature (Heath 1966). In our study, individuals of both species ended the experiments with body temperatures that corresponded with the selected body temperature of Liolaemus species (Labra et al. 2009), a proxy of the optimal body temperature (Huey 1982). Thus, the display would prevent a cranial overheating while individuals were achieving their optimum body temperature, because the head can be heated at a faster rate than the rest of the body due to its larger area to volume ratio (Heath 1964; Pough \& McFarland 1976). From our study, however, we cannot confirm that during the eye-bulging the lizards' heads were overheated, and that the display allowed decreasing the head-body temperature gradient, because we only measured the body (cloacal) temperature, and this was done at the end of the experiments. Nevertheless, considering that the other recorded individuals that did not display eye-bulging, also ended the trials with body temperatures similar as those that made the display, it is unlikely that the eye protrusion in these Liolaemus species is directly involved in thermoregulation. Future studies should test in liolaemid lizards the hypothesis that eye-bulging is a thermoregulatory mechanism, for example, by exposing lizards to a progressive increase of temperatures (e.g. Heath 1964), predicting a positive relation between the display frequency and the temperatures, if thermoregulation is the main cause of this display.
The eye-bulging recorded in these Liolaemus species might be modulated by other factors. We may partially accept the cleaning hypothesis, because although any of the lizards that displayed the behavior was shedding or had visible ectoparasites in the ocular region, one individual of $L$. chiliensis that exhibited the display had sand in one eyelid, and after performed the display, it rubbed its jaw against the substrate, releasing the particles; therefore, eye-bulging in L. chiliensis may allow cleaning sand from eyes.

Regardless of whether thermoregulation or eye cleaning are modulating the occurrence of the eye-bulging display, it is intriguing that it has been reported in very few species, only in species of the Iguania clade, and in laboratoy conditions. The fact that the display only has been observed in captivity, as in our study, may be the reflection that it is very hard to observe at long distances, as the eye movements can be very impercetibles and of very short duration. Moreover, as was previously indicated (Montanucci 1997), from our study we also can conclude that the display occurs at very low frequency, since in only $12 \%$ of all the videos we oberved this behavior. Therefore, the low frequency would make also hard to detect the display under natural conditions. In addition, laboratory conditions may generate adverse effects on lizard behaviour (e.g. thermoregulatory stress) compared to field conditions, which would increase the frequency of events of eye-bulging in captivity (Steyn \& Steyn 1970). For example, Dewitt (1967) observed that in summer the 
head-body temperature gradient of Dipsosaurus dorsalis was lower in the field than in laboratory conditions, and only in the latter condition it was observed eye-bulging. Finally, it is unclear if this display only occurs in Iguania lizards. Therefore, it is relevant to determine if other taxa of the superorden Lepidosauria exhibit the eye-bulging display, as well as, have more information on the display to get a better comprehesion of the factors that modulate this behaviour.

\section{ACKNOWLEDGEMENT}

We thank all the members of the Neuroetología lab, especially to C. Montesino, to C. Reyes for image editing and two anonymous reviewers for their important comments. C. Reyes-Olivares thanks the fellowships CONICYTPCHA: Magíster Nacional/2013-22130605, Doctorado Nacional/2015-21150353 and Fundación Guillermo Puelma (Universidad de Chile). Funds come from Fondecyt 1120181 (AL). This study was authorized by SAG (Resolution No. 7266) and by the Scientific Ethics Committee of the Faculty of Medicine, Universidad de Chile.

\section{BIBLIOGRAPHY}

BRUNER, H.L. 1907. On the cephalic veins and sinuses of reptiles, with description of a mechanism for raising the venous blood-pressure in the head. The American Journal of
Anatomy 7:1-117.

DeWitt, C.B. 1967. Precision of thermoregulation and its relation to environmental factors in the desert iguana, Dipsosaurus dorsalis. Physiological Zoology 40:49-66.

Heath, J.E. 1964. Head-body temperature differences in horned lizards. Physiological Zoology 37:273-279.

Heath, J.E. 1966. Venus shunts in the cephalic sinuses of horned lizards. Physiological Zoology 39:30-35.

Huey, R.B. 1982. Temperature, physiology, and the ecology of reptiles. In: Biology of the Reptilia (Eds. Gans, C. \& F.H. Pough), pp. 25-91. Academic Press, New York.

Labra, A., Pienaar, J. \& Hansen, T.F. 2009. Evolution of thermal physiology in Liolaemus lizards: adaptation, phylogenetic inertia, and niche tracking. The American Naturalist 174:204-220.

MontanuCCI, R.R. 1997. Captive management, behaviour and conservation of chuckwallas, Sauromalus obesus (Lacertilia: Iguanidae). Bulletin of the Chicago Herpetological Society 32:121-137.

Phillips, J.A. \& Harlow, H.J. 1981. Elevation of upper voluntary temperatures after shielding the parietal eye of Horned Lizards (Phrynosoma douglassi). Herpetologica 37:199205.

Pough, F.H. \& McFarland, W.N. 1976. Physical basis for headbody temperature differences in reptiles. Comparative Biochemistry and Physiology 53A:301-303.

Steyn, W. \& Steyn, S. 1970. New data on a sand-shuttling eyepopping lizard. Madoqua 2:39-44.

Tattersall, G.J., Cadena, V. \& Skinner, M.C. 2006. Respiratory cooling and thermoregulatory coupling in reptiles. Respiratory Physiology and Neurobiology 154:302-318.

Recibido: 21.11 .14

Aceptado: 12.01 .16 